\title{
Postgraduate Students' Acceptance of On-line Databases: A Validation of UTAUT Model in Selected Universities in Nigeria
}

\author{
Olawale Bamidele \\ University Library, Ekiti State University \\ Nigeria \\ Email: bamex001 [AT] gmail.com
}

\begin{abstract}
The purpose of this study was to validate the Unified Theory of Acceptance and Use of Technology (UTAUT) model on the acceptance of on-line databases among postgraduate students in Nigeria. the study investigated the four based constructs of UTAUT that is performance expectancy (PE), effort expectancy(EE), social influence (SI) and facilitating conditions (FCs) as the determinants of behavioural intention to use and eventual usage of on-line databases. The study adopted a descriptive survey research design. The population was made up of postgraduate students from Ekiti State University, Ado-Ekiti, and Federal University of Technology, Akure; Nigeria. Data were collected using questionnaire designed to elicit response from respondents and analysed using descriptive statistics method of frequency counts and percentages. However, out of two hundred and twenty five (225) copies of questionnaire administered to the respondents one hundred and eighty six (186) were returned which represents $82.7 \%$ response rate for the study. Findings revealed that all four variables i.e. (PE), (EE), (SI) and (FCs) had positive and significant effect on users' behavioural intention to use on-line databases. It was recommended that infrastructure such as computers and high-speed and affordable internet required are provided for easy access in Nigerian universities among other recommendations.
\end{abstract}

Keywords---- performance expectancy, effort expectancy, social influence, facilitating conditions, behavioural intention, on-line databases and postgraduate students

\section{INTRODUCTION}

Electronic information is provided in the form of purely bibliographic databases or bibliographic databases that links to full texts. On-line databases have become an established component of many academic libraries' collection. These databases often contain journal articles, or references to such articles, e-books, reference sources, conference papers and reports among others. There are various types of these databases such as bibliographic, full-text, directory, numeric and multimedia. On-line databases are widely available and can be accessed from anywhere and by many users at the same time. It is therefore convenient to use. University libraries, therefore, spend large amounts of money on these resources to satisfy the teaching, learning and research needs of its staff and students. As universities spend substantial amount of money on subscription of these databases, it is only appropriate and economical that these databases are optimally utilised to contribute to the academic development of students and also to get value for money (Bamidele, 2017).

Isah (2010) noted that numerous efforts have been made to launch African universities into the digital society with different initiatives by both national and international bodies. These initiatives provide the required networked infrastructure that enable African universities to have access to free or heavily discounted journals and databases through programmes like AGORA, elFL, HINARI, OARE, EBSCOhost, PERI etc. In addition to this, the Federal Government of Nigeria through the National Universities Commission (NUC) also initiated various programmes to launch Nigerian universities into information global society. Some of the projects initiated include automation of university libraries using Management Information Systems (MIS) and Nigerian Universities Network (NUNET) (Isah, 2010; Nok, 2006).

The degree to which on-line databases are accepted depends largely on a number of factors such as performance expectancy, effort expectancy, social influence and facilitating conditions. The Unified Theory of Acceptance and Use of Technology UTAUT model combines theoretical models and is made up of four key factors that act as determinants of behavioural intentions and usage of on-line databases. Also, UTAUT posits the role of four key moderator variables (age, gender, experience and voluntariness of use). Moreover, UTAUT model has been found to be reliable because it is able to account for a high percentage of the variance in usage intention (Venkatesh Morris, Davis and Davis, 2003).

The model was employed in four different organisational settings for a period of six months in Taiwan and the study showed significant predictive intention of its key constructs (performance expectancy, effort expectancy, social influence and facilitating conditions). Strong supportive empirical evidence had also been provided for UTAUT by a thorough analysis of data from four organisations and a cross-validation within two new organisations. In spite of the numerous applications, robustness, validation and high predictive capability of the model on the use of ICTs, several limitations have been attributed to it. Prominent among these limitations is the inability of the model to clearly indicate its 
two main components (social and technical) as well as its inability to emphasise the direct influence of facilitating conditions on behavioural intention to use technology.

Performance expectancy as a variable in UTAUT model refers to the degree to which individual perceives that using a system will help him or her to attain a gain in job performance (Venkatesh, et.al; 2003). Performance expectancy is assumed that the relative performance of on-line databases in terms of enhancing research productivity, access to current and relevant literature, comprehensiveness as well as improving pedagogy determine its use. In addition, Tan (2013) submitted that both performance expectancy and relative advantage of technology/system are related terms. In this case, the former reflects the belief that an information system helps in performing a function, while the relative advantage is focusing on the degree to which an innovation is perceived to be better than its precursor. Khayati and Zouaoui (2013) viewed perceived usefulness as the gain in performance that an individual believes he can get when using a technology.

Applying this construct to the use of on-line databases by postgraduate students, presents the benefits a postgraduate student believes he can derive from using on-line databases. It is expected that a postgraduate student will build interest in using on-line databases, if he/she perceives that it will improve his/her academic performance and research. This means that an individual can only embrace a new system with the positive disposition that it will improve his efficiency or quality of job output (Snicker, 2013). Performance expectancy has implications for the use of on-line databases by postgraduate students. This is simply because the way postgraduate students perceive on-line databases to be useful in provision of current and timely information in enhancing their academic performance will influence the use of the system.

Moreover, they are likely to be interested in comparing the costs and benefits of using on-line databases. It suffices to say that a user will only use a system due to the conviction that the system can provide answers to his/her queries. However, if postgraduate students perceive that on-line databases may not add value to their academic performance, they may decline the use of the system. Therefore, performance expectancy represents a critical factor in enhancing or hindering the use of on-line databases among postgraduate students.

Attuquayefio and Addo (2014), employed UTAUT model to analyse tertiary students' ICT adoption in Ghana and reported that some constructs of UTAUT (effort expectancy, performance expectancy and social influence) positively influenced behavioural intentions to use digital resources for learning by students. They further claimed that while facilitating conditions and behavioural intention directly influence students' use behaviour of ICT provided for learning and research. Only effort expectancy and facilitating conditions significantly predict students' intention to use ICT and ICT use behaviour of students respectively.

Liao and $\mathrm{Lu}$ (2011), examined factors of e-learning behavioural intention on cross-level analysis based on the Unified Theory of Acceptance and Use of Technology (UTAUT). They concluded that individual-level factors (performance expectations, effort expectancy, perceived behavioural control), and group-level factors (like colleague influence) have a positive effect on behavioural intention. Tibenderana et.al (2010) examined levels of end-users' acceptance and use of hybrid library services in developing countries with special interest in Uganda. Structural equation model was employed to expand the major constructs of UTAUT.

Another variable in this study that could influence the use of on-line databases among postgraduate students is effort expectancy. Effort expectancy is based on the idea that there are relationships between the effort put forth at work, the performance achieved from that effort, and the rewards received from the effort (Ghalandari, 2012). In terms of online databases, effort expectancy will mean clear interaction and easy to understand service, less mental effort in using service and the ability to perform tasks according to individual's requirements. Postgraduate students' use of on-line databases may likely be influenced by the perceived convenience of use of this system. Users of on-line databases are likely to be influenced by how easy or complex it is for them to access and retrieve relevant information from their preferred databases within shortest time possible.

Effort expectancy is the degree of ease associated with use of the system (Venkatesh, et.al; 2003). Effort expectancy combines theories from semantic viewpoints such as perceived ease of use (technology acceptance model), complexity from personal computer utilization model as well as diffusion of innovation theory. Extensive research has also given support for the effect of effort expectancy on intention to use a technology (Venkatesh, 2000; Venkatesh and Morris, 2000). The construct has also been found to be significant in both voluntary and mandatory context.

The third construct of the UTAUT model is social influence. Social influence connotes external pressures that can be exerted upon an individual or group of individuals to act in a particular way. It reflects the influence of variables such as opinions of family, close friends, and colleagues on usage behaviour. This can simply be represented as, opinions to which persons who are close to the user will be taken into account most of the time when making decision to adopt any new technology (Venkatesh et al., 2003). It also represents the degree to which individuals perceived the importance of using new technology by others. Hence, the construct could exert different influence on postgraduate students' viz-á-viz on-line databases use. The level of use of what constitute students' on-line databases use might be functions of many factors. It could be for gathering of articles for research work, collation of materials for conferences and workshops. Of all these, the influence of expansion of frontier of knowledge to get promoted to another level of academics appears to be paramount.

The fourth factor of UTAUT model is facilitating conditions. Facilitating conditions refers to the degree to which an individual believes that an organisational and technical infrastructure exist to support the system (Venkatesh et al., 2003). Facilitating conditions such as resources availability, skills as well as technical infrastructure seem to play a 
significant role towards on-line databases use among postgraduate students. This is the case why Bouten (2008) opines that students may not use an information system if there is absence of infrastructure like computer and internet facilities, technical know-how (literacy) as well as skills needed for information resources retrieval.

The term facilitating conditions is also one of the base constructs of UTAUT Model by Venkatesh, et.al; (2003). It represents the degree to which an individual believes that an organisational and technical infrastructure exists to support the use of a system. This construct was first used by Thompson, Higgins and Howell (1991) in Personal Computer Utilisation Model. Facilitating conditions covers definitions from perceived behavioural control (planned behavioural theory and decomposed planned behaviour theory) and adaptability from diffusion of innovation theory. It also involves the circumstances that an individual believes exist to support his/her activities, such as digital library (Phichitchaisopa and Naenna, 2013).

The construct was later adapted by Venkatesh et.al (2003) to establish its relationship with technology usage. In this context, facilitating conditions is described as the extent to which university lecturers believe that technical infrastructure exists to enhance the use of digital library. Therefore, in order to benefit from the potentials of digital library, it is necessary to build digital libraries with local contents, so that users can have access to the national resources and publications. The findings of Attuquayefio and Addo (2014) confirmed that irrespective of the performance or usefulness of the ICTs provided by the university authorities, the acceptance and use of such system will depend largely on the availability of support and facilities needed. The level of facilitation of these conditions will have significant influence on students' behavioural intention to use on-line databases.

Furthermore, it has been argued that availability of the requisite infrastructural and technical support within a system will in no small way encourage the use of digital resources. For example, Teo and Milutinovic (2015) employed subjective norm, knowledge of mathematics, and facilitating conditions as external variables to the Technology Acceptance Model (TAM) to examine the intention to use technology for teaching mathematics among pre-service teachers in Serbia. Structural equation model was used to analyse data gathered from the survey of 313 participants. The analysis revealed that the proposed model in this study has a good fit and accounted for $5.4 \%$ of the variance in the behavioural intention to use technology.

Pre-service teachers' attitudes towards computers were found to be the only factor with direct influence on the intention to use technology. All other factors were found to have an indirect influence. The results also show that facilitating conditions have a significant influence on pre-service teachers' perceived usefulness and perceived ease of use but not on attitudes towards computer use. The authors submitted that although pre-service teachers may perceive technology to be useful and easy to use in the presence of technical support, their attitude towards computers would not necessarily be influenced.

\section{BEHAVIOURAL INTENTION TO USE ON-LINE DATABASES}

The increase access to Information and Communication Technology (ICT) creates a new paradigm for postgraduates in their academic undertakings. More importantly, postgraduate students' behavioural intention plays a pivotal role at creating conscious plans to adopt and eventually make use of these technologies. Behavioural intention is described as the degree to which a person has formulated conscious plans to perform or not perform some specified future behaviour. Behavioural intention is an indication of an individual's readiness to perform a given behaviour (Ajzen, 2002). It is assumed to be an immediate antecedent of behaviour based on attitude toward the behaviour, subjective norm and perceived behavioural control, with each predictor weighted for its importance in relation to the behaviour and population of interest.

Overtime, several studies have emerged on the importance of behavioural intention towards acceptance and use of technologies such as the se of on-line databases. For example, Erasmus, Rothmann, and Eeden (2015) used structural model with a cross-sectional survey design to test the technology acceptance among South African students. They confirmed that there are significant paths from perceived usefulness of the information system to attitudes towards and behavioural intentions to use it. Furthermore, they submitted that behavioural intention to use the system predicted actual use thereof. Perceived ease of use indirectly affects attitudes towards and behavioural intentions to use via perceived usefulness of the information system.

Vogiatzi (2015) investigated the potential of perceived information technology beliefs, and employees ' personal and individual characteristics in Greek tourism centres. He also included personal characteristics and subjective norms factors to test behavioural intention to accept and use the information technologies in Greek tourist centres. The findings suggest that, in the Greek tourism sector, the harmonization of personal characteristics together with the other driving factors positively contributes, through a Technology Acceptance Model (TAM), to the enhancement of behavioural intention.

In assessing the behavioural intention of using technology, Venkatesh and Bala (2008) found in their study that job relevance and output quality had an interactive effect on perceived usefulness. They also reported that output quality as well as job relevance can facilitate perceived usefulness of technology. According to Allen (2005) technology relevance in modern day libraries cannot be underestimated. The adoption and use of e-resources and other ICT facilities has made it possible for the library presence (collections and services) to be felt beyond the four walls of a building complex. 
Similarly, Hong, Thong, Wong and Tam (2002) employed the technology acceptance model (TAM) as a theoretical framework to investigate the effect of a set of individual differences (computer self-efficacy and knowledge of search domain) and system characteristics (relevance, terminology, and screen design) on intention to use digital libraries. They selected 585 users of a university's award-winning digital library, their results strongly support the utilisation of TAM in predicting users' intention to adopt digital libraries, and demonstrate the effects of critical external variables on behavioural intention through perceived ease of use and perceived usefulness. They reported that all the individual differences and system characteristics have significant effects on perceived ease of use and perceived usefulness of digital libraries.

Given that an individual perceives that using a system will improve his job performance represents performance expectancy, convenience of use represents the effort expectancy while availability of technical and organisational infrastructure required to use a system represents the facilitating conditions. All these factors could be said to play a critical role and have direct impact on individual behavioural intention to use on-line databases. Performance expectancy, effort expectancy and facilitating conditions therefore, represent potential factors that could influence postgraduate students' behavioural intention to use on-line databases. It is on this premise that this study is being carried out to examine the postgraduate students' acceptance of on line databases: a validation of UTAUT model in two universities in Nigeria.

\section{OBJECTIVES OF THE STUDY}

The main objective of this study is to examine postgraduate students' acceptance of on-line databases: a validation of UTAUT model in two universities in Nigeria. The specific objectives are to:

i. find out the purpose of using on-line databases among postgraduate students in Ekiti State University (EKSU) and Federal University of Technology, Akure; Nigeria;

ii. determine how performance expectancy influence the use of on-line databases among postgraduate students in the selected universities.

iii. $\quad$ examine the influence of effort expectancy of postgraduate students to use on-line databases in the selected universities.

iv. determine how facilitating conditions influence the use of on-line databases among postgraduate students in the selected universities.

\section{METHODOLOGY}

The study adopted a descriptive research method and data were generated through the use of questionnaire which was administered on randomly selected students of Ekiti State University (EKSU) and Federal University of Technology, Akure. Items in the questionnaire focused on performance expectancy, effort expectancy, facilitating conditions and behavioural intention to use on-line databases. The use of frequency counts and percentages method of data analysis were adopted for this research work.

\section{PRESENTATION AND DISCUSSION OF RESULTS}

Below is the comprehensive analysis of data and findings based on the responses received from the respondents through the use of questionnaire. Out of the two hundred and twenty five (225) copies of questionnaire distributed, one hundred and eighty six (186) copies $(82.7 \%)$ were returned with valid responses.

Table 1: Distribution of Respondents by Institution and Gender

\begin{tabular}{|c|c|c|c|c|}
\hline S/N & Institution & Frequency & Male & Female \\
\hline 1 & EKSU & $115(61.8 \%)$ & $60(52.2 \%)$ & $55(47.8 \%)$ \\
\hline 2 & FUTA & $71(38.2 \%)$ & $43(60.6 \%)$ & $28(39.4 \%)$ \\
\hline & Total & $186(100 \%)$ & $103(55.4 \%)$ & $83(44.6 \%)$ \\
\hline
\end{tabular}

This table presents findings on the distribution of the respondents by institutions and gender. $61.8 \%$ of the respondents were from EKSU, while 38.2\% were from FUTA. From EKSU, 56.5\% of the respondents were male and $43.50 \%$ were female, $67.6 \%$ of the respondents from FUTA were male while the remaining $32.4 \%$ were female. 
Table 2: Performance Expectancy and digital library use

\begin{tabular}{|l|l|l|l|l|l|}
\hline & Items Relative advantage & VT & T & ST & NT \\
\hline 1 & $\begin{array}{l}\text { I find On-line Database resources more useful } \\
\text { than the conventional library resources }\end{array}$ & $59(31.7 \%)$ & $55(29.6 \%)$ & $38(20.4 \%)$ & $34(18.3 \%)$ \\
\hline 2 & $\begin{array}{l}\text { It is relatively cheaper to use On-line Database } \\
\text { resources than the conventional print resources }\end{array}$ & $54(29.0 \%)$ & $57(30.6 \%)$ & $49(26.3 \%)$ & $26(14.0)$ \\
\hline 3 & $\begin{array}{l}\text { On-line Databases design makes literature } \\
\text { search convenient and interesting }\end{array}$ & $62(33.3 \%)$ & $59(31.7 \%)$ & $37(19.9 \%)$ & $28(15.1 \%)$ \\
\hline 4 & $\begin{array}{l}\text { On-line Database resources have the potentials } \\
\text { to increase my academic performance }\end{array}$ & $60(32.3 \%)$ & $61(32.8 \%)$ & $40(21.5 \%)$ & $25(13.4 \%)$ \\
\hline 5 & $\begin{array}{l}\text { I am not sure if the use of On-line Databases } \\
\text { can improve my research work }\end{array}$ & $29(15.6 \%)$ & $38(20.4 \%)$ & $43(23.1 \%)$ & $76(40.9 \%)$ \\
\hline
\end{tabular}

Findings on performance expectancy and on-line database use revealed that $61.3 \%$ of the respondents are of the opinion that on-line database resources are more useful than the conventional library resources, while $59.6 \%$ of the respondents believed that it is relatively cheaper to use on-line database resources than the conventional print resources. Also, $65.1 \%$ of them agreed that it is true that on-line database resources have the potentials to increase their academic performance, and lastly only $36 \%$ of the respondents asserted that they were not sure if the use of on-line databases can improve my research work. This is in tandem with the position of Snicker, (2013) that an individual can only embrace a new system with the positive disposition that it will improve his efficiency or quality of job output. This is simply because the way postgraduate students perceive on-line databases to be useful in provision of current and timely information in enhancing their academic performance will influence the use of the system.

Table 3: Effort expectancy and On-line Database use

\begin{tabular}{|c|c|c|c|c|c|}
\hline & Items & VT & $\mathbf{T}$ & ST & NT \\
\hline \multicolumn{6}{|c|}{ Ease of use } \\
\hline 1 & $\begin{array}{l}\text { I don't require much mental effort to access On- } \\
\text { line Databases }\end{array}$ & $61(32.8 \%)$ & $59(31.7 \%)$ & $45(24.2 \%)$ & $21(11.3 \%)$ \\
\hline 2 & $\begin{array}{l}\text { I don't require much technical expertise to } \\
\text { effectively use On-line Databases }\end{array}$ & $52(28.0 \%)$ & $55(29.6 \%)$ & $42(22.6 \%)$ & $37(19.9 \%)$ \\
\hline 3 & $\begin{array}{l}\text { I can access On-line Database resources in the } \\
\text { comfort of my office without necessarily visiting } \\
\text { the library }\end{array}$ & $65(35.0 \%)$ & $61(32.8 \%)$ & $40(21.5 \%)$ & $20(10.8 \%)$ \\
\hline 4 & $\begin{array}{l}\text { Research and development is easier and faster } \\
\text { with On-line Databases }\end{array}$ & $70(37.6 \%)$ & $67(36.0 \%)$ & $39(21.0 \%)$ & $10(5.4 \%)$ \\
\hline \multicolumn{6}{|c|}{$\begin{array}{c}\text { Timeliness } \\
\end{array}$} \\
\hline 5 & $\begin{array}{l}\text { Speedy information retrieval makes the use of On- } \\
\text { line Databases less time-consuming }\end{array}$ & $68(36.6 \%)$ & $66(35.5 \%)$ & $40(21.5 \%)$ & $12(6.6 \%)$ \\
\hline 6 & $\begin{array}{l}\text { Using On-line Databases enables me conserve } \\
\text { time for other activities }\end{array}$ & $63(33.9 \%)$ & $61(32.8 \%)$ & $37(19.9 \%)$ & $25(13.4 \%)$ \\
\hline 7 & $\begin{array}{l}\text { The minimal time required to locate, access and } \\
\text { use digital resources makes On-line Databases } \\
\text { desirable }\end{array}$ & $65(35.0 \%)$ & $60(32.3 \%)$ & $41(22.0 \%)$ & $20(10.8 \%)$ \\
\hline \multicolumn{6}{|c|}{ Comprehensiveness } \\
\hline 9 & $\begin{array}{l}\text { Organisation of knowledge is simple in the On- } \\
\text { line Databases environment }\end{array}$ & $53(28.5 \%)$ & $50(26.9 \%)$ & $47(25.3 \%)$ & $36(19.4 \%)$ \\
\hline 10 & $\begin{array}{l}\text { Multiple search capability built into On-line } \\
\text { Databases makes its use a fascinating experiences }\end{array}$ & $58(31.2 \%)$ & $60(32.3 \%)$ & $52(28.0 \%)$ & $16(8.6 \%)$ \\
\hline 11 & $\begin{array}{l}\text { I don't use On-line Databases due to the ambiguity } \\
\text { of their resources }\end{array}$ & $38(20.4 \%)$ & $33(17.7 \%)$ & $56(30.1 \%)$ & $59(31.7 \%)$ \\
\hline 12 & $\begin{array}{l}\text { The infrastructure needed to access and use On- } \\
\text { line Database resources are simple ICT devices }\end{array}$ & $63(33.9 \%)$ & $59(31.7 \%)$ & $41(22.0 \%)$ & $23(12.4 \%)$ \\
\hline 13 & On-line Databases interface are not user-friendly & $27(14.5 \%)$ & $45(24.2 \%)$ & $55(29.6 \%)$ & $59(31.7 \%)$ \\
\hline
\end{tabular}

Findings on effort expectancy (ease of use) and on-line database use revealed that $64.5 \%$ of the respondents are of the opinion that they don't require much mental effort to access on-line databases. $57.6 \%$ of the respondents believed that they don't require much technical expertise to effectively use on-line databases, while $67.8 \%$ of them asserted that they can access on-line database resources in the comfort of my office without necessarily visiting the library. Also, $73.6 \%$ of the respondents are of the opinion that research and development is easier and faster with on-line databases. 
On timeliness and on-line database use, $72.1 \%$ of the respondents affirmed that speedy information retrieval makes the use of on-line databases less time-consuming, while $66.7 \%$ of them asserted that using on-line databases enables them conserve time for other activities and $67.3 \%$ of the respondents opined that minimal time is required to locate, access and use digital resources makes on-line databases desirable.

On comprehensiveness and on-line database use, 55.4\% of the respondents affirmed that organisation of knowledge is simple in the on-line databases environment and $63.5 \%$ of them asserted multiple search capability built into on-line databases makes its use a fascinating experience. Only $38.1 \%$ of the respondents opined that it was true that they don't use on-line databases due to the ambiguity of their resources, also, $65.5 \%$ of them affirmed that the infrastructure needed to access and use on-line database resources are simple ICT devices and lastly, only $38.7 \%$ of the respondents asserted that on-line databases interface are not user-friendly.

Table 4: Facilitating Conditions of using On-line Databases

\begin{tabular}{|l|l|l|l|l|l|}
\hline & Items & VT & T & ST & NT \\
\hline 1 & \multicolumn{1}{|c|}{ Resources (Human and Materials) } & & & \\
\hline 2 & $\begin{array}{l}\text { There is competent manpower to restore order in } \\
\text { the event of system breakdown }\end{array}$ & $43(23.1 \%)$ & $40(21.5 \%)$ & $50(26.9 \%)$ & $53(28.5 \%)$ \\
\hline $\begin{array}{l}\text { There is no provision of periodical training } \\
\text { programme on the use of On-line Databases and } \\
\text { its resources in my institution }\end{array}$ & $27(14.5 \%)$ & $22(11.8 \%)$ & $48(25.8 \%)$ & $89(47.8 \%)$ \\
\hline $\begin{array}{l}\text { The use of On-line Databases is not encouraged } \\
\text { in my institution }\end{array}$ & $33(17.7 \%)$ & $28(15.1 \%)$ & $55(29.6 \%)$ & $70(37.6 \%)$ \\
\hline 6 & $\begin{array}{l}|c| \\
\text { Thechnical infrastructure } \\
\text { help with technical issues }\end{array}$ & & & & \\
\hline 7 & $\begin{array}{l}\text { Internet access in my institution does not motivate } \\
\text { me to use On-line Databases }\end{array}$ & $58(31.2 \%)$ & $50(26.9 \%)$ & $45(24.2 \%)$ & $33(17.7 \%)$ \\
\hline 8 & $\begin{array}{l}\text { There is availability of constant electricity to } \\
\text { power ICT equipment }\end{array}$ & $30(16.1 \%)$ & $28(15.1 \%)$ & $49(26.3 \%)$ & $79(42.5 \%)$ \\
\hline 9 & $\begin{array}{l}\text { Available technical infrastructure are ineffective } \\
\text { and grossly inadequate }\end{array}$ & $65(35.0 \%)$ & $68(36.6 \%)$ & $39(21.0 \%)$ & $14(7.5 \%)$ \\
\hline 10 & $\begin{array}{l}\text { I don't use On-line Databases due to incessant } \\
\text { technical challenges }\end{array}$ & $58(31.2 \%)$ & $60(32.3 \%)$ & $3016.1 \%)$ & $8(4.3 \%)$ \\
\hline & \multicolumn{1}{|c|}{ Skills } & $65(35.0 \%)$ & $30(16.1 \%)$ & $16(8.6 \%)$ \\
\hline 11 & $\begin{array}{l}\text { I have the skills and the search ability to explore } \\
\text { On-line Database resources }\end{array}$ & $48(25.8 \%)$ & $53(28.5 \%)$ & $45(24.2 \%)$ & $40(21.5 \%)$ \\
\hline 13 & $\begin{array}{l}\text { I don't use On-line Databases due to ICT } \\
\text { incompetence }\end{array}$ & $18(9.7 \%)$ & $21(11.3 \%)$ & $58(31.2 \%)$ & $89(47.8 \%)$ \\
\hline 14 & $\begin{array}{l}\text { I don't use On-line Databases due to poor } \\
\text { information literacy skills }\end{array}$ & $22(11.8 \%)$ & $27(14.5 \%)$ & $61(32.8 \%)$ & $76(40.9 \%)$ \\
\hline 15 & $\begin{array}{l}\text { I find it difficult using On-line Databases due to } \\
\text { its complex terms }\end{array}$ & $29(15.6 \%)$ & $31(16.7 \%)$ & $58(31.2 \%)$ & $68(36.6 \%)$ \\
\hline
\end{tabular}

Findings on facilitating conditions of using on-line databases reveals that $23.1 \%$ of the respondents opined that there is competent manpower to restore order in the event of system breakdown, $14.5 \%$ of them asserted that it is very true that there is no provision of periodical training programme on the use of On-line Databases and its resources in their institutions, $17.7 \%$ of the respondents said that the use of On-line Databases is not encouraged in their institutions.

On technical infrastructure, $40.3 \%$ of the respondents opined that there is a central support unit in their institutions to help with technical issues, $31.2 \%$ of the respondents asserted it was very true that internet access in their institution does not motivate them to use on-line databases, also, only $16.1 \%$ of the respondents said it was very true there is availability of constant electricity to power ICT equipment, $35.0 \%$ of them opined it was very true that Available technical infrastructure are ineffective and grossly inadequate, $31.2 \%$ of the respondents asserted it very true they don't use On-line Databases due to incessant technical challenges. This confirm the findings of Attuquayefio and Addo (2014) that irrespective of the performance or usefulness of the ICTs provided by the university authorities, the acceptance and use of such system will depend largely on the availability of support and facilities needed. The level of facilitation of these conditions will have significant influence on postgraduate students' behavioural intention to use on-line databases.

On skills, $25.8 \%$ of the respondents opined agreed it was very true they have the skills and the search ability to explore on-line database resources, $47.8 \%$ of them asserted it was not true that they don't use on-line databases due to ICT incompetence, $40.9 \%$ noted it was not true they don't use on-line databases due to poor information literacy skills, $36.6 \%$ of the respondents noted it was not true that they find it difficult using on-line databases due to its complex terms, 
Table 5: Behavioural Intention to use On-line Databases

\begin{tabular}{|c|l|l|l|l|l|}
\hline S/N & Item & VT & $\mathrm{T}$ & $\mathrm{ST}$ & $\mathrm{NT}$ \\
\hline 1 & $\begin{array}{l}\text { I intend to use on-line databases for my class work } \\
\text { and assignment. }\end{array}$ & $58(31.2 \%)$ & $52(28.0 \%)$ & $40(21.5 \%)$ & $36(19.5 \%)$ \\
\hline 2 & $\begin{array}{l}\text { I plan to use on-line databases in the next one } \\
\text { month }\end{array}$ & $55(29.6 \%)$ & $54(29.0 \%)$ & $42(22.6 \%)$ & $35(18.8 \%)$ \\
\hline 3 & $\begin{array}{l}\text { I intend to frequently use on-line databases for my } \\
\text { academic work }\end{array}$ & $60(32.3 \%)$ & $57(30.6 \%)$ & $45(24.2 \%)$ & $24(12.9 \%)$ \\
\hline 4 & $\begin{array}{l}\text { I intend to continue using on-line databases for my } \\
\text { academic work }\end{array}$ & $58(31.2 \%)$ & $60(32.3 \%)$ & $49(26.3 \%)$ & $19(10.2 \%)$ \\
\hline 5 & $\begin{array}{l}\text { I intend to continue using on-line databases for my } \\
\text { information needs even after the completion of my } \\
\text { programme }\end{array}$ & $51(27.4 \%)$ & $55(29.6 \%)$ & $48(25.8 \%)$ & $32(17.2 \%)$ \\
\hline 6 & $\begin{array}{l}\text { Whenever possible, I intend to use on-line } \\
\text { databases as often as needed }\end{array}$ & $48(25.8 \%)$ & $50(26.9 \%)$ & $47(25.3 \%)$ & $41(22.0 \%)$ \\
\hline 7 & $\begin{array}{l}\text { If my library provides on-line databases I will use } \\
\text { them. }\end{array}$ & $56(30.1 \%)$ & $50(26.9 \%)$ & $48(25.8 \%)$ & $32(17.2 \%)$ \\
\hline
\end{tabular}

Findings on behavioural intention to use on-line databases revealed that $59.2 \%$ of the respondents opined it was true they intend to use on-line databases for their class work and assignment, 58.6\% of them asserted they plan to use on-line databases in the next one month, $62.9 \%$ noted it was true that they intend to frequently use on-line databases for their academic work, $63.5 \%$ of the respondents asserted that it was true they intend to continue using on-line databases for their academic work, $57.0 \%$ of them noted it was true they intend to continue using on-line databases for their information needs even after the completion of their programmes, $52.7 \%$ of the respondents asserted it was true they intend to use on-line databases as often as needed, whenever possible, lastly, $57.0 \%$ of them opined it was true if their library provides on-line databases they will use them.

\section{CONCLUSION AND RECOMMENDATIONS}

The university library plays a vital role in assisting the university to fulfil its goal. The effectiveness of the university library to a large extent depends on the utilisation of its resources and services. In order to achieve effective acceptance of on-line databases, extensive, attractive and insightful activities should be done to raise users' awareness of the advantages of on-line databases. Also, on-line databases should be designed in a way that users face no problems while using them. With respect to positive and significant effect of performance expectancy, effort expectancy, social influence and facilitating conditions on using on-line databases, it is recommended that infrastructure such as computers and high-speed and affordable internet required in is provided in Nigeria universities. There should be development of ICT infrastructure and procurement of on-line databases by University librarians to facilitate access to on-line databases. Information literacy programmes, orientations and other innovative strategies to encourage postgraduate students to use on-line databases.

\section{REFERENCES}

- Ajzen, I. 2002. Perceived Behavioural Control, Self-Efficacy, Locus of Control, and the Theory of Planned Behavior. Journal of Applied Social Psychology 32: 665-683.

- Bamidele, O. (2017) Database Resources. In Use of Library and Information Communication Technology Study Skills. Ado-Ekiti; Ekiti State University. Pg. 208-230.

- $\quad$ Erasmus, E., Rothmann, S. and Van Eeden, C. 2015. A structural model of technology acceptance. South African Journal of Industrial Psychology/SA Tydskrif vir Bedryfsielkunde, 41.1. Retrieved 8 May, 2015 from: http:// dx.doi.org/10.4102/sajip. v41i1.1222

- Ghalandari, K. 2012. The effect of performance expectancy, effort expectancy, social influence and facilitating conditions on acceptance of E-banking services in Iran: The moderating effect of age and gender. Middle-East Journal of Scientific Research 12.6:801-807

- Hwang, Y. and Yi, M. Y. 2002. Predicting the use of Web-Based Information Systems: Intrinsic Motivation and Self-Efficacy, Eighth Americas Conference on Information Systems 1076-1081

- Isah, A. 2010. Electronic library use by academic staff at the University of Ilorin, Nigeria. Journal of Library and Information Science (JOLIS), 7.1 \& 2: 138-149

- Nok, G. 2006. The challenges of computerizing a university library in Nigeria: The case of Kashim Ibrahim Library, Ahmadu Bello University, Zaria. Library Philosophy and Practice 8 (2) Retrieved $12^{\text {th }}$ August, 2015 from: http://www.webpages.uidaho.edu/ mbolin/nok.pdf 
- Liao, H. L., \& Lu, H. P. 2011. The role of experience and innovation characteristics in the adoption and continued use of e-learning websites. Computers and Education, 51, 4:1405-1416.

- Phichitchaisopa, N and Naenna, T. 2013. Factors Affecting the Adoption of Healthcare Information Technology, EXCLI Journal, 1. 2: 413-436

- $\quad$ Snicker, E. 2013. Employee Self-Service Technology Acceptance: A case study at TAP Portugal. Retrieved 5 October, 2014 from:http://.tap.itworld.selfservice.salacious.contentdriving-adoption

- Tan, P. J. B., 2013. Students' Adoptions and Attitudes towards Electronic Placement Tests: A UTAUT Analysis, American Journal of Computer Technology and Application 1. 1: 14 - 23

- Teo, T., and Milutinovic, V. 2015. Modelling the intention to use technology for teaching mathematics among pre-service teachers in Serbia. Australasian Journal of Educational Technology, 31.4: 363-380

- Tibenderana, P., Ogao, P., Ikoja-Odongo, J. and Wokadala, J. 2010. Measuring levels of end-users' acceptance and use of hybrid library services, International Journal of Education and Development using Information and Communication Technology (IJEDICT), 6.2: 33-54

- Venkatesh, V. and Bala, H. 2008. Technology Acceptance Model 3 and a Research Agenda on Interventions. Decision sciences. $39 . \quad 2 . \quad$ Retrieved 22nd June, 2014 from http://vvenkatesh.com/Downloads/Papers/fulltext/pdf/Venkatesh_Bala_DS_2008.pdf

- Venkatesh, V., Morris, M.G., Davis, G. B. and Davis, F. B. 2003. User Acceptance of Information Technology: Toward a Unified View. MIS Quarterly. 23. 3: 425-478.

- Vogiatzi, M. 2015. The use of ICT technologies enhances employees‘ performance in the Greek Hotel Industry, International Journal of Economics, Finance and Management Sciences 3.1: 43-56 